\title{
Provisional Measures and the Jadhav Case
}

Ravindra Pratap*

DOI: $10.21827 / 5 a 6 a f a 3 c 5 e 843$

\section{Keywords}

PROVISIONAL MEASURES, PRIMA FACIE JURISDICTION, PRESERVATION OF RIGHTS, URGENCY.

\begin{abstract}
The Jadhav Case is an interesting case which, besides adding to a discernible frequency of provisional measures disputes in international litigation, brings to the fore at least two aspects of particular importance: the evolution of the jurisprudence of the International Court of Justice (ICJ/Court) on the prerequisites for its indication of provisional measures and a noticeable break from the past in India's well-known attitude to adjudication of its disputes by the Court, particularly its disputes with Pakistan. This is not to underestimate the significance of human rights considerations that underlie the case. India's approaching the Court in this case seems to be an act of pragmatism dictated by domestic considerations rather than a general change in its attitude to adjudication of its disputes by the Court. Thus, nothing contrary to international law or jurisdictional bases of the Court may be inferred for or against India from its approaching the Court in this case. While the real motives behind India's Application may have been quite different, this is undoubtedly a positive development in international law, much of whose preoccupation critically remains the peaceful settlement of disputes, as a corollary to the jus cogens nature of its prohibition of the threat or use of force in international relations. This is even more important when seen in light of the fact that both India and Pakistan are declared nuclear weapons states with only India having a declared 'no-first-use' policy.
\end{abstract}

\section{Introduction}

The Indian national, Mr Kulbhushan Sudhir Jadhav, was arrested by Pakistan on 3 March 2016. ${ }^{1}$ On 25 March 2016, India made the first of its thirteen unsuccessful requests to Pakistan for consular access. ${ }^{2}$ Pakistan acknowledged that Mr Jadhav was an Indian national in its note verbale of 23 January 2017. ${ }^{3}$ On 21 March 2017, Pakistan informed India that consular access to Mr Jadhav would be considered 'in the light of' India's response to its request for assistance in the investigation against him in Pakistan. ${ }^{4}$ India protested this on 31 March 2017. On 10 April 2017, Pakistan informed India that Mr Jadhav had been sentenced to death following a Court Martial due to activities of 'espionage, sabotage and terrorism'. ${ }^{5}$ On 8 May 2017, India approached the ICJ, alleging persistent violations by Pakistan of the Vienna Convention on Consular

\footnotetext{
Associate Professor, Faculty of Legal Studies, South Asian University, New Delhi, India. Email: ravindrapratap@sau.int; ravindrapratap@hotmail.com. The author is grateful to the Journal for its invitation to make this contribution and to the anonymous reviewers of its earlier versions. India's Application Instituting Proceedings, 08 May 2017, at 4 [India's Application].

Ibid.

Ibid.

$I d, 6$.

Id, Annex: Press Statement by Mr. Sartaj Aziz, Adviser to the Prime Minister on Foreign Affairs on 14 April 2017.
} 
Relations of 24 April 1963 (Vienna Convention). ${ }^{6}$ By a letter dated 9 May 2017 addressed to the Prime Minister of Pakistan, the President of the Court, exercising the powers conferred upon him under Article 74(4) of the Rules of Court, ${ }^{7}$ called upon the Pakistani Government, pending the Court's decision on the request for the indication of provisional measures, 'to act in such a way as will enable any order the Court may make on this request to have its appropriate effects'. ${ }^{8}$ Later, on 18 May 2017, by way of indicating provisional measures, the Court ordered

'Pakistan shall take all measures at its disposal to ensure that Mr Jadhav is not executed pending the final decision in these proceedings and shall inform the Court of all the measures taken in implementation of the present order. ${ }^{\prime 9}$

The Jadhav Case is an interesting case which, besides adding to a discernible frequency of provisional measures cases in international litigation, ${ }^{10}$ testifies to a noticeable political shift in India's strategy to approach the Court in relation to its neighbour Pakistan, which became an independent country after partition of the British India in 1947. The ICJ is no exception to provisional measures, which are a common feature of national and international judicial procedures. Article 41 of the Statute empowers the Court 'to indicate, if it considers that circumstances so require, any provisional measures which ought to be taken to preserve the respective rights of either party.' The Court's jurisprudence shows a general consistency in its essential approach with some variations of form in particular cases. Accordingly, Part II discusses the requirement of the existence of a dispute, Part III focuses on the issue of prima facie jurisdiction, Part IV deals with the consideration of preservation of rights, Part V is on the question of the risk of irreparable prejudice, Part VI is on urgency, and finally part VII concludes.

\section{The Existence of a Dispute between India and Pakistan}

The Applicant, India, argued that the dispute submitted to the Court arises out of the interpretation and application of the Vienna Convention and lies within the compulsory jurisdiction of the Court under Article 1 of its Optional Protocol Concerning the Compulsory Settlement of Disputes. ${ }^{11}$ During the hearing, India added that the issues of

6 ICJ, Jadhav Case (India v. Pakistan), Provisional Measures, Order of 18 May 2017, paras 49-56, at < icjcij.org/files/case-related/168/168-20170518-ORD-01-00-EN.pdf> (accessed 19 November 2017) (Jadhav Provisional Measures Order). This was the second time that India approached the Court. See International Court of Justice, Appeal Relating to the Jurisdiction of the ICAO Council, Judgment, ICJ Reports 1972, 46.

7 Article 74 (4) of the Rules of Court, "the President may call upon the parties to act in such a way as will enable any order the Court may make on the request for provisional measures to have its appropriate effects."

8 Jadhav Provisional Measures Order, para 8.

9 Id, para 61 " $[\mathrm{I}] \mathrm{t}$ is crucial that such measures should operate directly where the preservation is required", Campbell McLachlan, "The Continuing Controversy over Provisional Measures in International Disputes", 7 International Law FORUM du droit international 5 (2005) 14.

10 See, for instance, the Enrica Lexie case between India and Italy currently on merits before the Permanent Court of Arbitration.

11 India's Application, supra nt 1, at 1. The provision states: "Disputes arising out of the interpretation or application of the Convention shall lie within the compulsory jurisdiction of the International Court of Justice and may accordingly be brought before the Court by an application made by any party to the dispute being a Party to the present Protocol." 
violation by Pakistan of the rules of international law led to the dispute. ${ }^{12}$ The counsel for India elaborated

'disputes have arisen between India and Pakistan when India asserts, and Pakistan presumably would deny, violations of the Vienna Convention. These disputes would relate, if not entirely, substantially to the interpretation of the Vienna Convention and to its application to the facts of the case. ${ }^{13}$

Pakistan, on the other hand, contended that Article 36 (1) of the Vienna Convention could not have been intended to apply to persons suspected of espionage or terrorism and that there can therefore be no dispute relating to the interpretation or application of that instrument in the present case. ${ }^{14}$ The Court ascertained whether, on the date of India's Application, such a dispute existed between the parties. ${ }^{15}$ Referring to the Indian position that Mr Jadhav be given consular assistance, and the stand of Pakistan that such assistance would be considered in the light of India's response to its request for assistance, the Court prima facie gathered the existence of 'a dispute between Indian and Pakistan as to the question of consular assistance under the Vienna Convention with regard to the arrest, detention, trial and sentencing of Mr. Jadhav. ${ }^{16}$

Thus, the existence of a dispute was a requirement for the assumption by the Court of its jurisdiction in the case. Inherent in this requirement is some necessity of prior diplomatic negotiations for the identification by the parties of issues of facts and law. ${ }^{17}$ If the correspondence between India and Pakistan is anything to go by, there is ample evidence of the fulfilment of the requirement of the existence of a dispute under the Vienna Convention. ${ }^{18}$

12 Statement by India's Deputy Agent, Verbatim Record, International Court of Justice, 15 May 2017, para 2.

13 Statement India's Counsel, Verbatim Record, International Court of Justice, 15 May 2017, para 44.

14 Jadhav Provisional Measures Order, para 24.

15 Id, para 28.

$16 \quad I d$, para 29.

17 Rosenne, S, The Law and Practice of the International Court, 1920-2005 (Kluwer 2006) 1154.

18 Further, see Permanent Court of International Justice, Mavrommatis Palestine Concessions (Greece $v$ Britain), PCIJ Series A, Judgement No 2, 30 August 1924, para 11; Permanent Court of International Justice Factory at Chorzów (Germany v Poland) Interpretation of Judgements No 7 and 8, Judgement No 11, PCIJ Series A, paras 10-11; International Court of Justice, South West Africa (Ethiopia v South Africa; Liberia $v$ South Africa) ICJ Reports 1962, 328 (Preliminary Objections, Judgement); International Court of Justice, Land and Maritime Boundary between Cameroon and Nigeria (Cameroon v Nigeria), Preliminary Objections, Judgement, ICJ Reports 1998, 297, para 39 and 322, para 109; International Court of Justice, Application of the International Convention on the Elimination of All Forms of Racial Discrimination (Georgia v. Russian Federation) ICJ Reports 2011 (I), 84, para 30, 94, para 51, 95, para 53 (Preliminary Objectons, Judgement); International Court of Justice, Questions relating to the Obligation to Prosecute or Extradite (Belgium v. Senegal) ICJ Reports 2012 (II), 443-445, paras 50-55; International Court of Justice, Alleged Violations of Sovereign Rights and Maritime Spaces in the Caribbean Sea (Nicaragua v. Colombia), Preliminary Objections, Judgment of 17 March 2016, para 50, citing Interpretation of Peace Treaties with Bulgaria, Hungary and Romania, First Phase, Advisory Opinion, ICJ Reports 1950, 74, and paras 71-73); International Court of Justice, Obligations Concerning Negotiations Relating to the Cessation of Nuclear Arms Race and to Nuclear Disarmament (Marshall Islands v India), Jurisdiction of the Court and the Admissibility of the Application, 5 October 2016, para 38. 


\section{Prima facie Jurisdiction}

The standard of determining the requirement of jurisdiction for adjudication of a request for provisional measures is somewhat different, at least less rigorous, than that of determining the requirement of jurisdiction for deciding on the merits. ${ }^{19}$ Thus, the Court was willing to indicate provisional measures

'only if the provisions relied on by the applicant appear, prima facie, to afford a basis on which its jurisdiction could be founded, but need not satisfy itself in a definitive manner that it has jurisdiction as regards the merits of the case. ${ }^{20}$

India had sought to found the jurisdiction of the Court on Article 36(1) of the Statute of the Court and Article I of the Optional Protocol concerning the Compulsory Settlement of Disputes, ${ }^{21}$ which accompanies the Vienna Convention, on Consular Relations.

The second limb of the Court's enquiry was whether the dispute between the parties was one over which it might have a subject-matter jurisdiction under Article I of the Optional Protocol. ${ }^{22}$ The Court noted that the acts alleged by India were capable of falling within the scope of Article 36(1) of the Vienna Convention, which guarantees the right of the sending State to communicate with and have access to its nationals in the custody of the receiving State, ${ }^{23}$ and the right of its nationals to be informed of their rights. ${ }^{24}$ The Court considered that the alleged failure by Pakistan to provide the requisite consular notifications with regard to the arrest and detention of Mr Jadhav, as well as the alleged failure to allow communication and provide access to him, appeared to be capable of falling as a subject matter within the scope of the Vienna Convention. ${ }^{25}$

The Court next enquired whether espionage or terrorism afforded any exception to the applicability of the Vienna Convention as Pakistan had alleged that Mr Jadhav was involved in espionage and terrorists activities. ${ }^{26}$ The Court found that the Convention contains no such express provisions that excludes from its scope persons suspected of espionage or terrorism. ${ }^{27}$ The final issue, having a bearing on the issue of prima facie jurisdiction, was of the relevance of the 2008 Agreement between India and Pakistan, ${ }^{28}$ which the latter had relied on to argue against the jurisdiction of the Court. The Court was of the view that it need not decide at the provisional measures stage of

19 On provisional measures, see generally, Mendelson, M, "Interim Measures of Protection in Cases of Contested Jurisdiction", 46 British Yearbook of International Law (1972-1973), 259; Collins, L, "Provisional and Protective Measures in International Litigation", 234 Recueil des Cours (1992), 9; Rosenne, S, Provisional Measures in International Law: The International Court of Justice and the International Tribunal for the Law of the Sea (Oxford University Press 2004); Miles, CA, Provisional Measures before International Court and Tribunals (Cambridge University Press 2017).

20 Jadhav Provisional Measures Order, para 15; Application of the International Convention for the Suppression of the Financing of Terrorism and of the International Convention on the Elimination of All Forms of Racial Discrimination (Ukraine v. Russian Federation), Provisional Measures, 19 April 2017, para 17.

21 See http://legal.un.org/ilc/texts/instruments/english/conventions/9_2_1963_disputes.pdf (accessed 25 November 2017).

22 Jadhav Provisional Measures Order, para 30.

23 Sub-paragraph (a) and (c) of the Vienna Convention.

24 Sub-paragraph (b) of the Vienna Convention.

25 Jadhav Provisional Measures Order, para 30.

26 India's Application, supra nt 1, Annex 2, Communication from the Pakistan Ministry of Foreign Affairs, 23 January 2017.

27 Jadhav Provisional Measures Order, para 32.

28 Agreement on the Consular Access between the Government of the Islamic Republic of Pakistan and the Government of the Republic of India, 2008, < treaties.un.org/Pages/showDetails.aspx?objid= 08000002804b7dde $>$ (accessed 12 November 2017). 
the proceedings 'whether Article 73 of the Vienna Convention would permit a bilateral agreement to limit the rights contained in Article 36 of the Vienna Convention. ${ }^{29}$ The Court noted that the 2008 Agreement does not limit those rights. ${ }^{30}$

The requirement of prima facie jurisdiction for indication of provisional measures is reasonable in the sense that the parties are not restrained by a court or tribunal when there is 'some plausible likelihood that it will in fact be in a position to deal with the merits of the dispute. ${ }^{31}$ The standard of determining prima facie jurisdiction ${ }^{32}$ has been greatly influenced by the ICJ's jurisprudence. ${ }^{33}$ There is prima facie jurisdiction where 'there is nothing which manifestly and in terms excludes the Tribunal's jurisdiction' ${ }^{34}$ and where the subject-matter of the dispute relates to the convention's 'interpretation or application', the existence of prima facie jurisdiction is reasonably established. ${ }^{35}$ Furthermore, while a subsequent agreement, such as the 2008 Agreement, is in principle admissible in the interpretation of a prior agreement, ${ }^{36}$ the terms of the 2008

29 Ibid.

30 Ibid.

31 Mensah, TA, "Provisional Measures in the International Tribunal for the Law of the Sea (ITLOS)", 62 ZaöRV (2002), 44 <zaoerv.de/62_2002/62_2002_1_a_43_54.pdf> (accessed 20 November 2017); ICJ, Fisheries Jurisdiction (Federal Republic of Germany v. Iceland) ICJ Reports 1972, 17 August 1972, 30, para 16; International Court of Justice, Nuclear Tests (Australia v. France) ICJ Reports 1973, 22 June 1973, 99, para 13; International Court of Justice, Aegean Sea Continental Shelf (Greece v. Turkey), ICJ Reports 1976, 11 September 1976, 3 and ICJ, Military and Paramilitary Activities in and Nicaragua (Nicaragua v. United States of America) ICJ Reports 1984, 10 May 1984, 1; International Court of Justice, Application of the Genocide Convention (Bosnia and Herzegovina v. Yugoslavia (Serbia and Montenegro)) 1 ICJ Reports 1993, 3, para 14; International Court of Justice, Vienna Convention on Consular Relations (Paraguay v. United States of America) ICJ Reports 1998, Order of 9 April 1998, 248, para 8; Addo, MK, and Evans, MD, "Vienna Convention on Consular Relations (Paraguay v. United States of America) and LaGrand (Germany v. United States of America), Applications for Provisional Measures", 48 International and Comparative Law Quarterly (1999) 673-681.

32 "[B]efore prescribing provisional measures the Tribunal need not finally satisfy itself that it has jurisdiction on the merits of the case and yet it may not prescribe such measures unless the provisions invoked by the Applicant appear prima facie to afford a basis on which the jurisdiction of the Tribunal might be founded", $M / V$ "Saiga" (No. 2), ITLOS Case No. 2, Provisional Measures, 11 March 1998, para 29.

33 It has been stated that "on a request for provisional measures the Court need not, before deciding whether or not to indicate them, finally satisfy itself that it has jurisdiction on the merits of the case, yet it ought not to indicate such measures unless the provisions invoked by the applicant appear, prima facie, to afford a basis on which the jurisdiction of the Court might be established." International Court of Justice, Legality of Use of Force (Yugoslavia v United States of America), Order of 2 June 1999, ICJ Reports 1999, 2 June 1999, 916, 923, para 20 (Yugoslavia v US).

34 Permanent Court of Arbitration (PCA), MOX Plant Case, Order No. 3, 24 June 2003, para 14 (MOX Plant $P C A)$.

35 International Court of Justice, Application of the International Convention on the Elimination of All Forms of Racial Discrimination (Georgia v Russian Federation) Provisional Measures, ICJ Reports 2008, Order of 15 October 2008, 353, para 117. See also International Court of Justice, Legality of Use of Force (Yugoslavia v United States of America), ICJ Reports 1999, 2 June 1999, 916, 923, para 21.

36 On subsequent agreement, see generally International Law Commission Guide, < legal.un.org/ilc/guide/1_11.shtml> (accessed 9 October 2017); International Court of Justice, Dispute regarding Navigational and Related Rights (Costa Rica v. Nicaragua) ICJ Reports 2009, 213 and 242, para 64; Murphy, SD, The relevance of subsequent agreement and subsequent practice for the interpretation of treaties, (Oxford University Press 2013), 89-90; Simma, B, Miscellaneous thoughts on subsequent agreements and practice (Oxford University Press 2013), 47; Alvarez, J, Limits of change by way of subsequent agreements and practice, in Treaties and Subsequent Practice, Nolte, G, ed. (Oxford University Press 2013), 130. 
Agreement were not found by the Court to restrict, at the provisional measures stage, the rights conferred by the Vienna Convention on Consular Relations. ${ }^{37}$

\section{Preservation of the Rights of the Parties}

Preservation of the respective rights claimed by the parties during pendency of a decision on the merits of the case is the object of the power of the Court under Article 41 of the Statute. ${ }^{38}$ In this respect, the Court needs to be convinced that the rights asserted by the party requesting provisional measures are plausible, i.e. the rights which may subsequently be adjudged by it to belong to either party. ${ }^{39}$ As the party requesting provisional measures, India asserted that the rights it is seeking to protect are those provided by paragraph 1 of Article 36 of the Vienna Convention. This provision contains the right of communication and access, the basic principle governing consular protection. ${ }^{40}$ Thus, all State parties to the Vienna Convention have a right to provide consular assistance to their nationals who are in prison, custody or detention in another State party and are entitled to respect for their nationals' rights contained therein. ${ }^{41}$

India claimed that its national, Mr Jadhav, was arrested, detained, tried and sentenced to death by Pakistan and that, despite its several requests, India was not given access to him. India pointed out that on 21 March 2017 Pakistan stated that 'the case for the consular access to the Indian national Kulbushan Jadhav shall be considered in the light of India['s] response to Pakistan's request for assistance' in the investigation process concerning him. India argued in this connection that the conditioning of consular access on assistance in the investigation was itself a serious violation of the Vienna Convention. ${ }^{42}$ Pakistan contested that it had conditioned consular assistance and averred that the rights invoked by India were not plausible because Article 36 of the Vienna Convention did not apply to persons suspected of espionage or terrorism and because the situation of Mr Jadhav was governed by the 2008 Agreement. $^{43}$

The Court observed that at the provisional measures stage, it is not required to determine definitively whether the rights, which India wishes to see protected, exist. It only needs to decide whether these rights are plausible. ${ }^{44}$ The Court considered that, at the provisional measures stage of the proceedings where the parties had advanced no legal analysis on these questions, Pakistan's arguments did not provide a sufficient basis

37 Jadhav Provisional Measures Order, para 33. Further, see generally Merrills, JG, "Interim Measures of Protection and the Substantive Jurisdiction of the International Court", 36(1) Cambridge Law Journal (1977) 86-109; Peter, J, and Bernhardt, A, "The Provisional Measures Procedure of the International Court of Justice through US Staff in Tehran: Fiat Iustitia, Pereat Curia", 20 Virginia Journal of International Law (1980) 557-613, 575 et seq.

38 Jadhav Provisional Measures Order, para 35.

39 Ibid. Further, see International Court of Justice, Application of the International Convention for the Suppression of the Financing of Terrorism and of the International Convention on the Elimination of All Forms of Racial Discrimination (Ukraine v. Russian Federation), Order of 19 April 2017, para 63. Further, see Buys, CG, "Application of the International Convention on the Elimination of All Forms of Racial Discrimination (Georgia v. Russian Federation)", 103 American Journal of International Law 294-299 (2009), 296.

40 Jadhav Provisional Measures Order, para 38, quoting LaGrand, ICJ Reports 2001, 492, para 74.

41 Jadhav Provisional Measures Order, para 39.

$42 I d$, para 40.

43 Id, para 41.

44 Id, para 42. Application of the International Convention for the Suppression of the Financing of Terrorism and of the International Convention on the Elimination of All Forms of Racial Discrimination (Ukraine v. Russian Federation), Order of 19 April 2017, para 64. 
to exclude the plausibility of the rights claimed by India. ${ }^{45}$ Further, the Court noted that Pakistan did not challenge India's submissions that its national Mr Jadhav was neither afforded access nor informed of his rights of consular assistance. ${ }^{46}$ The Court therefore found India's rights to be plausible. ${ }^{47}$

Since provisional measures are properly sought for the preservation of the rights of the parties, the plausibility of those rights becomes a relevant consideration. ${ }^{48}$ The requirement of the plausibility of the rights also underlies the ICJ's practice on provisional measures, ${ }^{49}$ which means that the rights asserted by the applicant merit judicial recognition. ${ }^{50}$ The plausibility requirement is now firmly rooted in the ICJ's jurisprudence on the indication of provisional measures. ${ }^{51}$

Furthermore, in advancing the claim of restitution in integrum by declaring that the sentence of the military court violated international law, India had argued that Pakistan was in defiance of basic human rights of an accused which are also to be given effect as mandated under Article 14 of the 1966 International Covenant on Civil and Political Rights (ICCPR). ${ }^{52}$ There is no trace in the Order of the Court applying considerations of humanity otherwise than stating that all state parties to the Vienna Convention are entitled to respect for their nationals' rights contained therein. ${ }^{53}$ Nonetheless, this is not the first case in which considerations of humanity were affirmed. ${ }^{54}$ '[T] he evolving jurisprudence on provisional measures shows a growing tendency to recognise the human realities behind disputes of states. ${ }^{, 55}$ Recently, in the Enrica Lexie Case, both the International Tribunal for the Law of the Sea (ITLOS) ${ }^{56}$ and the Arbitral Tribunal ${ }^{57}$ took human rights considerations into account in prescribing provisional measures. The Inter-American Court of Human Rights (Inter-American Court) noted that Article 36 of the Vienna Convention serves a dual purpose,

45 Jadhav Provisional Measures Order, para 43.

46 Id, para 44.

47 Id, para 45.

48 See also Article 290(1) of the United Nations Convention on the Law of the Sea, 1982.

49 International Court of Justice, Questions Relating to the Obligation to Prosecute or Extradite (Belgium v. Senegal), Provisional Measures, ICJ Reports 2009, Order of 28 May 2009, 139, 151 (Belgium v Senegal). Further, see ICJ, Certain Activities Carried Out by Nicaragua in Border Area (Costa Rica v Nicaragua), Provisional Measures Order, 8 March 2011 paras 53-54 at <icj-cij.org/docket/files/150/16324.pdf> (accessed 19 November 2017) ("[T]he Court may exercise this power [to indicate provisional measures] only if it is satisfied that the rights asserted by a party are at least plausible."). But see the separate opinion of Judge Koroma, para 12 at < icj-cij.org/docket/files/1 50/16326.pdf > (accessed 19 November 2017).

50 ICJ, Request for Interpretation of the Judgment of 15 June 1962 in the Case Concerning the Temple of Preah Vihear (Cambodia v. Thai), Provisional Measures Order, T 33 (July 18, 2011) (declaration of Judge Koroma), at <icj-cij.org/docket/files/151/16564.pdf > (accessed 19 November 2017).

51 Cogan, JK, "Current Developments: The 2011 Judicial Activity of the International Court of Justice", 106 American Journal of International Law 586 (2012), 599.

52 India's Application Instituting Proceedings, 31.

53 Jadhav Provisional Measures Order, para 39. On 10 November 2017, Pakistan decided to arrange a meeting of $\mathrm{Mr}$ Jhadav "with his wife, in Pakistan, purely on humanitarian grounds" at $<$ mofa.gov.pk/pr-details.php?mm=NTYxMg, (accessed 20 November 2017).

54 ICJ, Corfu Channel Case (UK v. Albania) (Merits), ICJ Reports 1949, 4, 22.

55 Higgins, R, "Interim Measures for the Protection of Human Rights", 36 Columbia Journal of Transnational Law (1997), 91, 108.

56 Enrica Lexie (Italy v India) ITLOs Case No. 24, Provisional Measures, ITLOS Order of 24 August 2015.

57 Enrica Lexie (Italy v India) PCA Case No. 2015-28, Provisional Measures, para 132 [Arbitral Tribunal's Order]. 
'that of recognising a State's right to assist its nationals through the consular officer's actions and, correspondingly, that of recognising the correlative right of the national of the sending State to contact the consular officer to obtain that assistance. $^{58}$

On the basis of the text of the Convention and its preparatory records, the InterAmerican Court concluded that Article 36 'endows a detained foreign national with individual rights that are the counterpart to the host State's correlative duties. ${ }^{59}$ The Inter-American Court thus rejected the US argument and found that Article 36 of the Convention concerns the protection of human rights and is part of the body of international human rights law. ${ }^{60}$ This does not, however, lead to the conclusion that provisional measures are clearly available for the protection of human rights. ${ }^{61}$

\section{A. Nexus between the Rights and the Provisional Measures}

Having established that it had jurisdiction in the case and the rights asserted by India were plausible, the ICJ turned to the question of whether there existed a link between the rights sought to be protected and the provisional measures requested. ${ }^{62}$ The Court noted that the provisional measures sought by India consisted of ensuring that the Government of Pakistan would take all measures necessary to prevent Mr Jadhav from being executed before the Court rendered its final decision. ${ }^{63}$ Since the Court considered that these measures were aimed at preserving the rights of India and of Mr Jadhav under Article 36(1) of the Vienna Convention, a link existed between the rights claimed by India and the provisional measures it had sought. ${ }^{64}$

The purpose of the preservation of the parties' rights is to prevent any serious prejudice to the rights of either party during pendency of the case on merits. ${ }^{65}$ However, there must be a link between the provisional measure(s) requested and the right(s) the requesting party claims to derive from the pending judgment. ${ }^{66}$ Also, provisional measures 'should have the effect of protecting the rights. ${ }^{67}$ In other words, any

58 The Right to Information on Consular Assistance in the Framework of the Guarantees of the Due Process of Law, Inter-American Court of Human Rights, Advisory Opinion No. OC-16/99, para 45 (1999).

$59 \quad I d$, para 84.

60 Further, see Aceves, WJ, "International Decisions: The Right to Information on Consular Assistance in the Framework of the Guarantees of the Due Process of Law, Inter-American Court of Human Rights, Advisory Opinion OC-16-99", 94 American Journal of International Law (2000), 555-563. Further, see generally Allen, FC, "Human Rights and the International Court: The Need for a Juridical World Order", 35 American Bar Association Journal (1949), 713-749.

61 See for instance Duxbury, A, "Saving Lives in the International Court of Justice: The Use of Provisional Measures to Protect Human Rights", 31 California Western International Law Journal 141-176 (2000).

62 Jadhav Provisional Measures Order (No 6), para 46, Application of the International Convention for the Suppression of the Financing of Terrorism and of the International Convention on the Elimination of All Forms of Racial Discrimination (Ukraine v. Russian Federation), Provisional Measures, Order of 19 April 2017, para 64.

63 Jadhav Provisional Measures Order (No 6), para 47.

64 Id, para 48.

65 ICJ, Certain Criminal Proceedings in France (Republic of the Congo v. France), Provisional Measure, Order of 17 June 2003, ICJ Reports 2003, 102, para 41 and 29.

66 Request for Interpretation of the Judgement of 15 June 1962 in the Case Concerning Temple of Preah Vihear (Cambodia v. Thailand), Provisional Measures, Order of 18 July 2011, para 34.

67 Polish Agrarian Reform and the German Minority, Interim Measures of Protection, Order of 29 July 1933, PCIJ Series A/B, No. 58, 175, 177; International Court of Justice, Passage through the Great Belt (Finland $v$ Denmak), Provisional Measures, Order of 29 July 1991, ICJ Reports 1991, 12, para 16 (Great Belt ICJ 
connection between the rights at issue and the requested provisional measures is not enough.

\section{Risk of Irreparable Prejudice}

The ICJ has the power to indicate provisional measures when irreparable prejudice could be caused to rights which are the subject of judicial proceedings. ${ }^{68}$ According to the Court, the mere fact that Mr Jadhav is sentenced to death and might therefore be executed is sufficient to demonstrate the existence of the risk of irreparable prejudice. ${ }^{69}$

The ground of irreparable prejudice to the rights of the parties in the assessment of whether provisional measures are called for is well-founded. ${ }^{70}$ On this ground, the ICJ recently rejected the Congo's application ${ }^{71}$ as it did not believe that criminal proceedings pending in France risked irreparable prejudice to the Congo's rights. ${ }^{72}$ It

Order). Further, see Essoff, PA, "Finland v Denmark: A Call to Clarify the International Court of Justices Standards for Provisional Measures", 15 Fordham International Law Journal (1991-1992), 839878, 847 et seq.

68 Jadhav Provisional Measures Order, para 49. Further, see International Court of Justice, Application of the International Convention for the Suppression of the Financing of Terrorism and of the International Convention on the Elimination of All Forms of Racial Discrimination (Ukraine $v$ Russian Federation), Provisional Measures, ICJ General List 166, Order of 19 April 2017, para 88. For a backgound,on the ICJ and PCIJ practice, see PCIJ, Denunciation of the Treaty of 2 November 1865 Between China and Belgium (Belgium v China) 1927 PCIJ Series A, No 8, 7 [(Belgium v China PCIJ); International Court of Justice, Fisheries Jurisdiction (United Kingdom v Iceland; Federal Republic of Germany $v$ Iceland), Provisional Measures, ICJ Reports 1972, Order of 17 August 1972, 16, paras 21-22 and 22-23, respectively (ICJ Fisheries Jurisdiction); International Court of Justice, Aegean Sea Continental Shelf (Greece v Turkey), Provisional Measures, ICJ Reports 1976, Order of 11 September 1976, 11, paras 31-33; International Court of Justice, United States Diplomatic and Consular Staff in Tehran (United States v Iran), Provisional Measures, ICJ Reports 1979, Order of 15 December 1979, 9, 19, 36, 37 (Hostage Case); International Court of Justice, Frontier Dispute (Burkina Faso v Mali), Provisional Measures, ICJ Reports 1986, Order of 10 January 1986, 12, 10, para 21; International Court of Justice, Application of the Convention on the Prevention and Punishment of the Crime of Genocide (Bosnia and Herzegovina $v$ Yugoslavia (Serbia and Montenegro)), Provisional Measures, ICJ Reports 1993, Order of 13 September 1993, 18, 19, 24, paras 3, 32 and 52; Oda, S, "Provisional Measures: The Practice of the International Court of Justice", in V. Lowe and M. Fitzmaurice (eds.), Fifty Years of the International Court of Justice: Essays in Honour of Robert Jennings (Cambridge University Press 1996), 542; LaGrand (Germany v United States of America) Provisional Measures, ICJ Reports 1999 (I), Order of 3 March 1999, 9, para 22 (LaGrand); Rosenne supra nt 17; International Court of Justice, Request for Interpretation of the Judgment of 15 June 1962 in the Case Concerning Temple of Preah Vihear (Cambodia v Thailand), Provisional Measures, Order of 18 July 2011; International Court of Justice, Certain Activities Carried Out by Nicaragua in the Border Area (Costa Rica v. Nicaragua), Provisional Measures, ICJ Reports 2011, Order of 8 March 2011, 6; Uchkunova, I, "Provisional Measures before the International Court of Justice", 12 The Law \& Practice of International Court and Tribunals (2013), 391.

69 Jadhav Provisional Measures Order, para 53.

70 Permanent Court of International Justice, Denunciation of the Treaty of 2 November 1865 Between China and Belgium (Belgium v. China) 1927 PCIJ Series A, No. 8, 7; International Court of Justice, Fisheries Jurisdiction (United Kingdom v Iceland; Federal Republic of Germany v Iceland) (Provisional Measures), ICJ Reports 1972, Order of 17 August 1972, 16, paras 21-22 and 22-23 (ICJ Fisheries Jurisdiction); International Court of Justice, Frontier Dispute (Burkina Faso/Mali), Provisional Measures, ICJ Reports 1985, Order of 30 December 1985, 10, para 21. See also Sztucki, J, "Case Concerning Land and Maritime Boundary (Cameron v Nigeria): Provisional Measures Order of 15 March 1996", 10 Leiden Journal of International Law (1997) 341-358, 352 et seq.; Hayashi, M, "Prescription of Provisional Measures by the International Tribunal for the Law of the Sea", 13 Tulane Environmental Law Journal (2000) 361-385 , 382; Kempen, B, and He, Z, "The Practice of the International Court of Justice on Provisional Measures: The Recent Development”, 69 ZaöRV(2009) 919-929, 921.

71 International Court of Justice, Certain Criminal Proceedings in France (Republic of the Congo $v$ France), Provisional Measure, ICJ Reports 2003, Order of 17 June 2003, 102, para 41 (Congo v France).

72 Further see ICJ Fisheries Jurisdiction, supra nt 68, 16. 
was found to be central by the Annex VII tribunal in the MOX Plant Case. ${ }^{73}$ Even quasijudicial bodies have required irreparable prejudice for the indication of provisional measures. ${ }^{74}$ A link must be established between the alleged rights, the protection of which is the subject of the provisional measures being sought, and the subject of the proceedings before the Court on the merits of the case.$^{75}$ Relatedly, there is evidence of varying practice on taking provisional measures to prevent aggravation or extension of the dispute. ${ }^{76}$ However, the "notion of aggravation seems to include a broader category of conduct than that covered by the notion of irreparable harm. ${ }^{77}$ The Court in this case was expressly concerned with irreparable prejudice and thus had required provisional measures to regulate a narrower category of conduct. This seems to be quite reasonable if understood ratione temporis in jurisdictional terms.

\section{Urgency}

Yet another critical consideration before the Court was urgency. The Court noted considerable uncertainty about a decision on appeal and when Mr Jadhav could be executed. Referring to Pakistan's statement that Mr Jadhav's execution would probably not take place before the end of August 2017, the Court inferred that his execution could take place at any moment thereafter and before the Court has given its final decision. Further, in the absence of any assurance from Pakistan that Mr Jadhav will not be executed before the Court has rendered its final decision, the Court was satisfied that there was urgency in this case. ${ }^{78}$ In doing so, the Court clarified, it merely acted as an adjudicator of the rights between states and not 'as a court of criminal appeal. ${ }^{79}$

Provisional measures are necessary 'if there is urgency in the sense that action prejudicial to the rights of either party is likely to be taken. ${ }^{80}$ However, the consideration of urgency has been stated, not in Article 41 of the ICJ Statute, but the Court's Rules. ${ }^{81}$ ICJ Judges have formally introduced urgency, ${ }^{82}$ although the ICJ is not

73 Order No. 3, Permanent Court of Arbitration, Order of 24 June 2003, para 58.

74 The Rule on provisional measures of the Human Rights Committee speaks of avoiding 'irreparable damage to the victim of the alleged violation' (Rule 92/Rule 86 old). Similarly, the Rule 108(1) of the Rules of Procedure of the Committee against Torture (CAT) and Article 5 of the Optional Protocol to the Women's Convention speak of avoiding irreparable damage to the victim or victims of the alleged violations. The Committee on the Elimination of Racial Discrimination (CERD) under its Rule 94(3) of Rules of Procedure refers to avoiding 'possible irreparable damage to the person or persons who claim to be victim(s) of the alleged violation'. The African Commission also speaks of avoiding irreparable damage 'to the victim of the alleged violation'.

75 International Court of Justice, Application of the International Convention on the Elimination of All Forms of Racial Discrimination (Georgia v Russian Federation) Provisional Measures, I.C.J. Reports 2008, Order of 15 October 2008, 353, para 118.

76 Permanent Court of International Justice, Electricity Company of Sofia and Bulgaria, Interim Measures of Protection, PCIJ Series A/B, Order of 5 December 1939, 194, 199; International Court of Justice, Armed Activities on the Territory of the Congo (DRC v Uganda), Provisional Measures, ICJ Reports 2000, Order of 1 July 2000, 111, para 44; ICJ, Pulp Mills on the River Uruguay (Argentina $v$ Uruguay), Provisional Measures, ICJ Reports 2006, Order of 13 July 2006, 113, paras 49-50.

77 Palchetti, P, "The Power of International Court of Justice to Indicate Provisional Measures to Prevent the aggravation of a Dispute", 21 Leiden Journal of International Law (2008) 623-642, 628.

78 Jadhav Provisional Measures Order, para 54.

79 Id, para 56.

80 Great Belt ICJ Order, supra nt 67, para 23.

81 Article 74 provides, "The Court, if it is not sitting when the request is made, shall be convened forthwith for the purpose of proceeding to a decision on the request as a matter of urgency."

82 Rosenne, supra nt 19, 135. 
an exceptional institution requiring it. ${ }^{83}$ Urgency relates to the imminent irreparable prejudice because 'if no irreparable prejudice is imminent[,] there is no urgency' ${ }^{84}$ Thus, the ICJ recently rejected the Congo's application, as noted above. ${ }^{85}$ Also, irrespective of the formulations of the relevant legal provisions, international courts and tribunals have required a linkage between urgency and a certain nature of harm to the parties' rights for the indication of provisional measures. ${ }^{86}$ The ICJ requires that a request for the indication of provisional measures be submitted in good time. ${ }^{87}$

\section{Conclusions}

The justification of guarding the rights of one party by the action of another party pending adjudication of the case on merits remains a relevant consideration in the administration of justice, and to that end, provisional measures have been reasonably termed as a general principle of law. ${ }^{88}$ However, it is of late that provisional measures have become a conspicuously more discernible feature in the practice of judicial settlement of international disputes, perhaps due mainly to the ICJ's ruling that they have binding effect. ${ }^{89}$

The Jadhav Case is an interesting case currently under litigation between India and Pakistan before the Court. While neither provisions of law nor issues of facts would necessarily set this case apart from other cases involving provisional measures, it nevertheless brings to the fore at least two aspects of particular importance. First, the evolution of the Court's jurisprudence on the prerequisites for its indication of provisional measures, and second, a significant break from the past in India's attitude to adjudication of its disputes by the Court, particularly its disputes with Pakistan. This is not to underestimate the significance of human rights considerations that evidently underlie the case (as more recently in the Enrica Lexie Case between India and Italy).

Contemporary developments in judicial settlement of international disputes have influenced the evolution of the Court's jurisprudence on provisional measures which has expressly required its prima facie jurisdiction, something which is to be found more discernible in the jurisprudence of ITLOS and the Permanent Court of Arbitration (PCA) for being stated in the 1982 United Nations Convention on the Law of the Sea and not in the ICJ's jurisprudence for being expressly absent as a requirement from the text of the relevant Article 41 of its Statute. Indeed, the Rules of the Court are also without any express reference to the requirement of prima facie jurisdiction. The point is not whether a finding of prima facie jurisdiction is any more than a non-definitive

83 See for instance, Article 290(5) of the United Nations Convention on the Law of the Sea, 1982. Further, see Polymenopoulou, E, "African Court on Human and Peoples' Rights, African Commission on Human and Peoples' Rights v. Great Socialist People's Libyan Arab Jamahiriya, Order for Provisional Measures 25 March 2011", 61 International and Comparative Law Quarterly (2012), 767-775.

84 Zimmerman, A, et al. eds., The Statute of the international court of justice: A commentary (2006), 940. See also Rosenne, supra nt 19, 136.

85 Congo v France, supra nt 65 and supra nt 71.

${ }^{86}$ Id, para 35; MOX Plant PCA, supra nt 34, para 58; Permanent Court of Arbitration, Indus Waters Kishenganga Arbitration (Pakistan v India), Interim Measures, paras 141-45 23 September 2011, at <pcacases.com/web/sendAttach/1682> (accessed 19 November 2017); Ghandhi, S, "International Court of Justice-Application of the International Convention on the Elimination of All Forms of Racial Discrimination (Georgia v Russian Federation), Provisional Measures Order of 15 October 2008", 58 International and Comparative Law Quarterly 713-725 (2009), 724.

87 ICJ, LaGrand (Germany v United States of America) Provisional Measures, ICJ Reports 1999 (I), Order of 3 March 1999, 9, para 19.

88 Jiménez de Aréchaga held in the Aegean Sea Continental Shelf case ICJ Rep 1976, 3, 15-16.

89 ICJ, LaGrand (Germany v United States of America) (Judgment) ICJ Reports 2001, 506, para 109. 
finding and the Court remains free not to exercise its jurisdiction even where it was not qualified as prima facie when found by the Court.

India's approaching the Court in the Jadhav Case seems to be an act of pragmatism dictated by domestic considerations rather than a general change in its known position on adjudication of its disputes by the Court. Thus, nothing contrary to international law and jurisdictional bases of the Court may be inferred for or against India from its approaching the Court in this case. While the real motives behind India's Application may have been different, this is undoubtedly a positive development in international law much of whose preoccupation critically remains the peaceful settlement of disputes as a corollary to the jus cogens nature of its prohibition of the threat or use of force in international relations. This is even more important when seen in light of the fact that both India and Pakistan are declared nuclear weapons states with only India having a declared 'no-first-use' policy. 